\title{
EFFECTS OF NITROGEN FERTILIZATION ON CORIANDER (CORIANDRUM SATIVUM L.): YIELD AND QUALITY CHARACTERISTICS
}

\author{
IZGI, M. N. \\ Kiziltepe Technical Vocational School of Higher Education, Mardin Artuklu University, \\ Mardin, Turkey \\ e-mail: necatizgi@hotmail.com; phone: +90-532-655-3083; ORCID: 0000-0003-1657-1169
}

(Received 21 $1^{\text {st }}$ May 2020; accepted $16^{\text {th }}$ Sep 2020)

\begin{abstract}
Coriander (Coriandrum sativum L.) is a spice plant belonging to the Apiaceae family. In this study, the aim was to specify the effects of different nitrogen doses on the yield and quality properties of coriander. In this research; plant height, number of branches, number of umbels, thousand seed weight, seed yield, oil content, fatty acid composition, essential oil rate and essential oil composition were examined. The essential oil contents in coriander fruits was determined by Clevenger apparatus. Fatty oil was isolated by cold press. Essential oil and fatty oil compositions were determined by Gas chromatography-mass spectrometry (GC/MS-QP2020) device. While nitrogen doses did not positively affect fruit yield, they had a significantly positive effect on the herbal characteristics of coriander (plant height, number of umbels and thousand fruit weight). It was revealed that nitrogen doses had positive significant effect essential oil rate. Increasing nitrogen doses affected rate of linalool. Nitrogen doses had a significant effect only on butyric acid, and for fatty oil rate and other major fatty acids their effect was not significant. It has been determined that high fruit yields are obtained at 60 and $80 \mathrm{~kg} \mathrm{ha}^{-1}$ nitrogen applications and that the rate of essential oil and linalool is the highest at $100 \mathrm{~kg} \mathrm{ha}^{-1}$ nitrogen doses especially in the second year.
\end{abstract}

Keywords: Coriandrum sativum, essential oil, fatty oil, linalool, nitrogen doses

\section{Introduction}

Coriandrum sativum L. is a medicinal and spice plant belonging to the Apiaceae family. It is named as "kişniş" in Turkish and "coriander" in English and is one of the oldest spices in the world. Its matured fruits and fresh leaves are used as spices and traditional medicine. Matured fruits contain between $0.03-2.7 \%$ of essential oil. The major component of the oil is linalool, accounts for about two-thirds of the oil (Shahwar et al., 2012). Essential oil of coriander is used in cosmetic industry because of the valuable components such as linalool.

The variation of essential oil content and composition in essential oil plant depends on their genetic structure, climatic conditions and agronomic applications (Telci et al., 2006a,b, 2010). The commercial value of coriander fruit is determined by its physical properties, chemical composition and bioactive effects (Furan and Geboloğlu, 2017). The essential oil and main component linalool are important raw materials in the perfume, cosmetic and pharmaceutical industries. It is also used in food and preventive medicine due to its bactericidal and fungicidal effects.

As in other medicinal and spice plants, in coriander, quality is as important as yield. The effects of cultural practices and environmental factors on these plants are more common than all other cultivated plants. Nitrogen is a plant nutrient that is effective not only in terms of growth and yield, but also in terms of seed quality, it plays an important role in the synthesis of plant components with the effect of different enzymes (Jr. Jones et al., 1991; Marschner, 2011). Nitrogen fertilization increases plant growth, essential oil, fixed oil and total carbohydrate and soluble sugar. Nitrogen is involved in photosynthesis, respiration and protein synthesis. It gives the leaves their dark green color, promotes hard vegetative 
growth and leads to more efficient use of existing inputs and ultimately to higher productivity (Pawar et al., 2007). Khalid (2013) stated that in the nitrogen dose applications, the values obtained were significantly higher than those of the control group and that they found significant results in plant growth characteristics.

Coriander production has been increasing day by day in Mardin province, as in different regions of Turkey. However, in the region where the experiment is carried out, there are not enough studies related to coriander cultivation, especially the need for nitrogen and the relationship between nitrogen and yield and quality. The yield of coriander is low in Mardin and its vicinity compared to the actual yield potential due to unsuitable fertilization and agricultural practices. For this reason, the research was carried out in order to evaluate the nitrogen demand of the registered Gamze cultivar in Mardin region of Turkey under the plain conditions of Mardin province and to find the effect of different nitrogen levels on yield and quality.

\section{Material and Methods}

Coriander (Coriandrum sativum L.) is a spice plant belonging to the Apiaceae family, which is used. As plant material; Gamze variety, which adapts to the plain conditions of Mardin province and is preferred by farmers, was used. This study was carried out for two years under plain conditions of Mardin Province in Turkey during the 2014-2015 and 20152016 vegetation periods.

Experiment area has a hot and dry weather in summers and rainy and warm in winters. Table 1 shows the climatic data for the application area. While the total rainfall data of January in the first year that the study was conducted and of April in the second year, were low compared to the average of long years, the total amount of precipitation in the other months was parallel to the average of long years. In the first and second years, monthly average temperature and humidity values were similar to the temperature average values of long years.

Table 1. Some meteorological data for long years (2004-2016) * and 2014-2015-2016 growing periods in Mardin province **

\begin{tabular}{|c|c|c|c|c|c|c|c|c|c|}
\hline & \multicolumn{3}{|c|}{ Rainfall (mm) } & \multicolumn{3}{|c|}{ Temperature $\left({ }^{\circ} \mathrm{C}\right)$} & \multicolumn{3}{|c|}{ Relative humidity (\%) } \\
\hline Months & $\begin{array}{l}\text { Long } \\
\text { Years }\end{array}$ & $\begin{array}{c}2014- \\
2015\end{array}$ & 2015-2016 & $\begin{array}{l}\text { Long } \\
\text { Years }\end{array}$ & $\begin{array}{r}2014- \\
2015\end{array}$ & 2015-2016 & $\begin{array}{l}\text { Long } \\
\text { Years }\end{array}$ & $\begin{array}{c}2014- \\
2015\end{array}$ & 2015-2016 \\
\hline November & 33.3 & 76.8 & 46.0 & 14 & 12.7 & 12.4 & 51.6 & 53.1 & 50.3 \\
\hline December & 54.8 & 100.4 & 34.8 & 9.1 & 5.8 & 7.3 & 54.3 & 72.2 & 51.7 \\
\hline January & 42.8 & 8.3 & 73.2 & 7.1 & 6.8 & 5.2 & 60.3 & 66.6 & 75.2 \\
\hline February & 47.6 & 76.0 & 35.8 & 8.8 & 8.2 & 11.0 & 60.0 & 68.7 & 65.8 \\
\hline March & 34.2 & 89.9 & 59.9 & 13.1 & 10.8 & 12.0 & 52.0 & 60.3 & 59.0 \\
\hline April & 37.7 & 25.4 & 9.3 & 17.5 & 14.0 & 17.4 & 49.3 & 53.0 & 41.3 \\
\hline May & 17.3 & 11.1 & 12.3 & 23.7 & 21.2 & 21.0 & 37.0 & 37.3 & 42.0 \\
\hline June & 2.4 & 0.2 & 0.5 & 30.5 & 26.9 & 29.1 & 22.8 & 29.0 & 28.2 \\
\hline July & 0.4 & 0.0 & 0.0 & 34.1 & 33.1 & 32.5 & 22.0 & 19.6 & 22.4 \\
\hline
\end{tabular}

*Long Years Means: Long years average: It is the average of the data of at least 10 years.

**Sources: Turkish State Meteorological Service

The soil has a clay-loam structure and is poor in organic matter $(1.18 \%)$. It is slightly alkaline $(\mathrm{pH}=8.05)$, lime content is very high $(36.65 \%)$, and no salinity problems $(0.010 \%)$. Phosphorus $(31.50 \mathrm{~kg})$, potassium $\left(104.16 \mathrm{mg} \mathrm{kg}^{-1}\right)$ is sufficient for soil uptake. 
Magnesium (292.6 mg kg-1), copper (19.134 mg ha-1), zinc $\left(0.8112 \mathrm{mg} \mathrm{kg}^{-1}\right)$ and iron (7.9050 mg kg $\left.\mathrm{g}^{-1}\right)$ are sufficient in the soil structure, but manganese $\left(3.390 \mathrm{mg} \mathrm{kg}^{-1}\right)$ is very low (Table 2).

Table 2. Soil properties of the experimental area*

\begin{tabular}{c|c|c|c}
\hline Analyzes (0-30 cm) & Limit Values & Analysis results & Analysis Method \\
\hline Phosphor (P) & $<3$ Trace & $29.2 \mathrm{mg} \mathrm{kg}^{-1}$ & TS ISO 11263 \\
Potassium (K) & $>30$ Sufficient & $111.44 \mathrm{mg} \mathrm{kg}^{-1}$ & TS 8341 \\
Lime (\%) & $>25$ Excessive calcic & $33.39 \%$ & TS EN ISO 10693 \\
pH & $7.5-8.5$ Light Alkaline & 8.08 & TS ISO 10390 \\
Organic substance (\%) & 1-2 Little & $1.15 \%$ & TS8336 \\
Salinity (\%) & $<2$ Salt-free & $0.010 \%$ & TS ISO 11265 \\
Mangan (Mn) & 4-14 Insufficient & $5.150 \mathrm{mg} \mathrm{kg}^{-1}$ & TUZUNER 1990 \\
Iron (Fe) & $>4.5$ Sufficient & $11.121 \mathrm{mg} \mathrm{kg}^{-1}$ & TUZUNER 1990 \\
Copper (Cu) & $>0.2$ Sufficient & $33.000 \mathrm{mg} \mathrm{kg}^{-1}$ & TUZUNER 1990 \\
Zinc (Zn) & $>$ 8 Excessive & $11.314 \mathrm{mg} \mathrm{kg}^{-1}$ & TUZUNER 1990 \\
Calcium (Ca) & 1150-3500 Sufficient & $1216.6 \mathrm{mg} \mathrm{kg}^{-1}$ & TUZUNER 1990 \\
Magnesium (Mg) & 160-480 Sufficient & $250.6 \mathrm{mg} \mathrm{kg}^{-1}$ & TUZUNER 1990 \\
Sodium (Na) & -- & $64.68 \mathrm{mg} \mathrm{kg}^{-1}$ & TUZUNER 1990 \\
Organic Carbon & -- & $0.67 \%$ & TS8336 \\
Carbon/Nitrogen (C/N) & -- & $0.55 \%$ & Calculation method \\
Structure & Sand 39 .2\%- Silt 28.0\% & CL (Clayey loamy) & TUZUNER A.1990 \\
\hline
\end{tabular}

Source: MARTEST analysis laboratories

The experiment was set up according to the Randomized Blocks Experiment Design with three replications. In the trial area, 5 different doses $\left(0,40,60,80\right.$ and $\left.100 \mathrm{~kg} \mathrm{ha}^{-1}\right)$ of nitrogen (Ammonium sulphate) were applied on the soil. The plot area has an area of totally $4.5 \mathrm{~m}^{2}$ as 5 rows on each plot with $3 \mathrm{~m}$ length, $1.5 \mathrm{~m}$ width and $30 \mathrm{~cm}$ planting distance. In the plantation, $1 \mathrm{~m}$ distance between plots and $2 \mathrm{~m}$ between blocks were arranged. The number of plants in the study was arranged as 66000 plant ha $^{-1}$. Sowings were performed manually on 15 October 2014 in the first year and 16 October 2015 in the second year. After the sowing, weeding was performed three times and irrigation was made 5 times in the summer months. On June 22, the harvest performed manually; calculations were made on the current area by removing $25 \mathrm{~cm}$ as edge effect from the row tops and one row on the sides.

\section{Essential oil and fatty oil analysis}

Volumetric method was used to determine the extraction and quantity of essential oils for distillation in ripe fruits; Coriander fruits are ground and exposed to distillation with Clevenger apparatus for 2.5 hours (Clevenger, 1928). The essential oil samples obtained were kept in the refrigerator at $4{ }^{\circ} \mathrm{C}$ until analysis.

In the fatty oil extraction method, fatty acids were converted to methyl ester derivatives, $0.1 \mathrm{~g}$ oil was taken in a $15 \mathrm{ml}$ plastic centrifuge with a lid and $10 \mathrm{ml}$-hexane was added. It was strongly shaken after closing its lid and $2 \mathrm{~N} \mathrm{KOH}$ solution with methanol $(0.5 \mathrm{ml})$ was appended. It was strongly shaken again after closing its lid and left 
in a dark environment for 2 hours until the supernate clarified. For analysis, the supernate was exposed to GC method and after that the sample was prepared for the analysis.

Fatty acids were dissolved in $40 \mathrm{mg}$ of oil $\mathrm{n}$-heptane for methylation prior to analysis. The tube was rinsed off with $2 \mathrm{M} \mathrm{KOH}(2 \mathrm{~mL})$ and then for phase formation was waited. The supernatant containing the fatty acids was taken in vials and diluted in n-hexane. Fatty oil and essential oil component analysis performed with the GC/MS-QP2020. GC/MS conditions were given in Table 3.

Table 3. GC/MS conditions

\begin{tabular}{|c|c|}
\hline System & GC/MS-QP2020 \\
\hline GC capillary column & $\begin{array}{c}\text { For Essential Oil Analysis: } \\
\text { Rtx-2330 RESTEK }(60 \mathrm{~m} \times 0.25 \mathrm{~mm} \times 0.2 \mu \mathrm{m}) \\
\text { For Fatty Oil Analysis: } \\
\text { Rtx-2330 RESTEK }(60 \mathrm{~m} \times 0.25 \mathrm{~mm} \times 0.2 \mu \mathrm{m})\end{array}$ \\
\hline Injection Mode & Split \\
\hline Pressure & $\begin{array}{l}\text { For Essential Oil Analysis: } 80 \mathrm{kPa} \\
\text { For Fatty Oil Analysis: } 100 \mathrm{kPa}\end{array}$ \\
\hline Split Rate & $\begin{array}{l}\text { For Essential Oil Component Analysis: } 25 \\
\text { For Fatty Oil Component Analysis: } 100\end{array}$ \\
\hline $\begin{array}{l}\text { GC oven initial } \\
\text { temperature }\end{array}$ & $\begin{array}{l}\text { For Essential Oil Component Analysis: Initial } 400^{\circ} \mathrm{C} 2 \text {-min. holding period } 4{ }^{\circ} \mathrm{C} \\
\text { min.-1 until } 240^{\circ} \mathrm{C} \text { Final temperature } 2400^{\circ} \mathrm{C} .3 \mathrm{~min} \text {. holding period } \\
\text { For Fatty Oil Component Analysis: Initial } 140^{\circ} \mathrm{C} 5 \text {-min. holding period } 4{ }^{\circ} \mathrm{C} \text { min. }{ }^{-1} \\
\text { until } 240^{\circ} \mathrm{C} \text { Final temperature } 240^{\circ} \mathrm{C} .15 \mathrm{~min} \text {. holding period }\end{array}$ \\
\hline $\begin{array}{l}\text { Injection block } \\
\text { temperature }\end{array}$ & $\begin{array}{l}\text { For Essential Oil Component Analysis: } 240^{\circ} \mathrm{C} \\
\text { For Fatty Oil Component Analysis: } 250^{\circ} \mathrm{C}\end{array}$ \\
\hline FID Temperature & $250^{\circ} \mathrm{C}$ \\
\hline Injection Volume: & $1 \mu 1$ \\
\hline
\end{tabular}

\section{Data analysis}

Agronomic characteristics of the study were analyzed by using the JMP 5.0.1 statistical program (SAS Institute Inc., 2002), and the differences between means of nitrogen doses were compared using Student's t-test at the 0.05 probability level (Gosset, 1908).

For essential oil and fatty oil, the analysis was applied using the IBM SPSS Statistics for Windows (IBM Corp., 2017). The significance of year differences of essential oil and fatty acids between fruit samples was tested by analysis of variance (ANOVA) and represented by critical value from an F-test $(F)$ and statistical significance (p). Essential oil means, fatty oil means, major components of essential oil and fatty acids with significant variation were compared by using Duncan Multiple Range Test (Duncan, 1955). Year difference significances were compared by T-test.

\section{Results and Discussion}

For coriander (Coriandrum sativum L.), data on the effect of different nitrogen doses on plant characteristics were given in Table 4 and on quality characteristics were given in Table 5, Table 6, Table 7 and Table 8. 


\section{Agronomic characteristics and yield}

\section{Plant height $(\mathrm{cm})$}

When the different nitrogen doses in coriander were examined in terms of plant height, the difference between years was insignificant and the difference between nitrogen doses was statistically significant $(\mathrm{p}<0.05)$ and interaction factor was insignificant. Regarding the average value of two years, the highest value was found to be $62.8 \mathrm{~cm}$ in $60 \mathrm{~kg} \mathrm{ha}^{-1}$ nitrogen application group and the lowest value was found to be $39.2 \mathrm{~cm}$ in the control group. After the application of $60 \mathrm{~kg}$ of nitrogen per hectare, decreases were observed in plant height $(61.6$ and $57.0 \mathrm{~cm})($ Table 4$)$. Nitrogen fertilization was found to have a negative effect on plant height when the optimum dose given to the plant was exceeded.

Table 4. Some agronomical characteristics of different nitrogen dose applications in coriander (Coriandrum sativum L.) *

\begin{tabular}{|c|c|c|c|c|c|c|c|c|c|c|c|}
\hline \multirow{2}{*}{$\begin{array}{c}\text { Nitrogen } \\
\text { Doses } \\
\left(\mathrm{kg} \mathrm{ha}^{-1}\right)\end{array}$} & \multicolumn{2}{|c|}{$\begin{array}{l}\text { Plant Height } \\
\text { (cm) }\end{array}$} & \multicolumn{3}{|c|}{$\begin{array}{c}\text { Number of } \\
\text { Branches } \\
\left.\text { (piece plant }^{-1}\right)\end{array}$} & \multicolumn{2}{|c|}{$\begin{array}{c}\text { Number of } \\
\text { umbels } \\
\left(\text { piece plant }^{-1}\right)\end{array}$} & \multicolumn{2}{|c|}{$\begin{array}{c}1000 \text { fruit weight } \\
\text { (g) }\end{array}$} & \multicolumn{2}{|c|}{$\begin{array}{l}\text { Fruit yield } \\
\left(\mathrm{kg} \mathrm{ha}^{-1}\right)\end{array}$} \\
\hline & 20152016 & Mean & 2015 & 2016 & Mean & 20152016 & Mean & 20152016 & Mean & 20152016 & Mean \\
\hline 0 & & & & 7.7 & & 10.213 .4 & & $\begin{array}{ll}12.3 & 11.7\end{array}$ & & 16862267 & \\
\hline 40 & 53.656 .9 & $55.3 \mathrm{c}$ & 4.5 & 5.8 & 5.2 & 12.216 .3 & 14.3ab & $\begin{array}{ll}13.0 & 12.7\end{array}$ & & 18832529 & 2206 \\
\hline 60 & 62.063 .6 & 62.8a & 4.3 & 5.1 & 4.7 & $10.8 \quad 9.5$ & $10.1 \mathrm{c}$ & $\begin{array}{ll}12.7 & 12.0\end{array}$ & $12.4 b$ & 21362266 & 2201 \\
\hline 80 & 61.162 .2 & & 4.9 & 5.4 & 5.2 & $12.8 \quad 13.5$ & 13.1ab & $12.8 \quad 12.7$ & & 20272721 & 2374 \\
\hline 100 & 55.358 .7 & $57.0 \mathrm{bc}$ & 5.4 & 6.1 & 5.8 & $\begin{array}{ll}15.1 & 14.5 \\
\end{array}$ & $14.8 \mathrm{a}$ & $\begin{array}{ll}13.5 & 13.3\end{array}$ & $13.4 a$ & 20172282 & 2150 \\
\hline Mean & 54.056 .3 & & 4.8 & 6.0 & & 12.213 .4 & & $\begin{array}{ll}12.9 & 12.5\end{array}$ & & 19502413 & \\
\hline
\end{tabular}

* Different letters after the same column data indicate significant difference at the 0.05 level or similar

In his study about effect of different fertilizers effect on coriander, Kan (2007) found effect of DAP (include 18\% nitrogen) fertilizer on plant height as insignificant. Erdoğdu and Esendal (2018), in their study about cultivar and nitrogen doses, specified significant $(p<0.01)$ positive relation between nitrogen doses and plant height. They determined that plant height varies between $90.20-109.40 \mathrm{~cm}$ regarding to mean data of doses. According to Okut and Yildırım (2005) effect of nitrogen doses on plant height is insignificant. However, Karadoğan et al. (1997) and Kırıcı et al. (1997) stated a positive significant relation between nitrogen doses and plant height.

\section{Number of branches per plant}

The difference between the number of branches by years, the difference between average of years in terms of fertilizer doses and interaction factors were found to be insignificant. The mean number of branches was found to be 4.8 in the first year and 6.0 in the second year. Regarding the average of two years, the highest number of branches was obtained in the control group (6.2 piece plant $^{-1}$ ), and the lowest number of branches (4.7 piece plant ${ }^{-1}$ ) was obtained with $60 \mathrm{~kg} \mathrm{ha}^{-1}$ nitrogen application. It was observed that increased nitrogen doses did not affect the number of branches in the plant (Table 4).

Kan (2007) found effect of DAP fertilization and year interaction on number of branches as significant $(\mathrm{p}<0.05)$ and according to mean data, he obtained that number of 
branches varies between 3.76- 5.09 with DAP fertilization and year interaction. Khalid (2013) obtained significant relation of number of branches and nitrogen doses and measured values between $2.8-7.1 \mathrm{~cm}$ for coriander. In literature statistically significant increase was observed parallel to increasing nitrogen doses (Karadoğan et al., 1997; Kırıc1 et al., 1997; Nayak et al., 2009).

\section{Number of umbels per plant}

The difference in the number of umbels by years was found to be insignificant and the difference between nitrogen dose applications was found to be significant $(p<0.05)$. It was calculated that there were 12.2 umbels per plant in 2015 and 13.4 umbels in 2016. It was found that the highest number of umbels by the average of years is $100 \mathrm{~kg} \mathrm{ha}^{-1}$ in nitrogen application and the lowest number of umbels is (10.1 plants) in $60 \mathrm{~kg} \mathrm{ha}^{-1}$ nitrogen application (Table 4). Applications over $60 \mathrm{~kg}$ of nitrogen per hectare resulted in a decrease in the number of umbels in the plant. In different nitrogen dose applications (up to $60 \mathrm{~kg} \mathrm{ha}^{-1}$ ), the number of umbels decreased as the plant height increased. The values obtained regarding the number of umbels: Some researchers do not find any significant effect of nitrogen doses on number of umbels per plant (Karadoğan et al., 1997; Okut and Yıldırım, 2005; Erdoğdu and Esendal, 2018). However, Kırıc1 et al. (1997) stated that nitrogen application has positive significant effect on number of umbels per plant and found values between 13.15-16.80 umbels per plant.

1000 fruit weight $(g)$

Regarding thousand fruit weight, difference by years was insignificant and the difference between nitrogen dose averages was significant $(\mathrm{p}<0.05)$. In the first year a thousand fruit weight was found to be $12.9 \mathrm{~g}$ and in the second year it was found to be $12.5 \mathrm{~g}$. The highest average value $(13.4 \mathrm{~g})$ was obtained in $100 \mathrm{~kg} \mathrm{ha}^{-1}$ nitrogen application, and the lowest value (12.0 g) was obtained in the control group (Table 4).

In previous studies conducted on 1000 seeds, Kan (2007) did not find any significant effect of nitrogen doses on thousand seed weight, Kandemir (2010); Karadoğan et al. (1997) and Okut and Yildırım (2005) obtained significant positive effect of nitrogen doses on thousand seed weight and they found values between; $7.01 \mathrm{~g}-8.25 \mathrm{~g} ; 9.74 \mathrm{~g}-11.06 \mathrm{~g}$ and $8.01 \mathrm{~g}-8.77 \mathrm{~g}$, respectively.

The highest weight of 1000 fruits at the highest nitrogen dose $\left(100 \mathrm{~kg} \mathrm{ha}^{-1}\right)$ indicates that nitrogen increases protein accumulation in fruits (Pawar et al., 2007). It can be said that the differences in thousand fruit weight in coriander stem from different agricultural practices as well as environmental differences as in other herbal characteristics.

Fruit yield $\left(\mathrm{kg} \mathrm{ha}^{-1}\right)$

The effect of different nitrogen dose applications on seed yield and the difference between the year averages were found to be insignificant. Yield per hectare in the first year was determined as $1950 \mathrm{~kg}$ in the first year and as $2413 \mathrm{~kg}$ in the second year. Regarding the different nitrogen doses average, the highest value $\left(2374 \mathrm{~kg} \mathrm{ha}^{-1}\right)$ was obtained in the $80 \mathrm{~kg} \mathrm{ha}^{-1}$ nitrogen application and the lowest value $\left(1976 \mathrm{~kg} \mathrm{ha}^{-1}\right)$ was obtained from the control group (Table 4).

Kan (2007) and Reddy and Rolston (1997) did not found any significant effect for nitrogen application on fruit yield, Patel et al. (2013) found significant relation and obtained $1203 \mathrm{~kg}$ from the application of $80 \mathrm{~kg}$ of nitrogen per hectare. Karadoğan et al. 
(1997) and Okut and Yildirım (2005) stated that increasing nitrogen doses cause an increase in seed yield. Kirıc1 et al. (1997) found significant effect and measured highest value as $1780 \mathrm{~kg} \mathrm{ha}^{-1}$ at $60 \mathrm{~kg} \mathrm{ha}^{-1}$ nitrogen application. Erdoğdu and Esendal (2018) found significant positive effect and obtained values between $982.0-1467.0 \mathrm{~kg} \mathrm{ha}^{-1}$ in coriander. Akbarinia et al. (2007), in their nitrogen amount experiment, found that there was a significant increase in seed yield at $60 \mathrm{~kg} \mathrm{ha}^{-1}$ nitrogen application.

In fruit yield, genetic control was found to be more dominant than nitrogen fertilization.

\section{Quality characteristics}

\section{Essential oil rate}

Variation in essential oil rate was given in Tables 5 and 6 . Variation of mean data of years in essential oil content was not significant statistically and means are the same for both years as $0.18 \%$. While main factor of year was not significant, doses and interaction factors were significant $(\mathrm{p}<0.01)$. Regarding to mean data of doses, statistically $(\mathrm{p}<0.05)$ highest value was obtained at $80 \mathrm{~kg}$ nitrogen per hectare application as $0.20 \%$; statistically $(\mathrm{p}<0.05)$ lowest value was obtained at control group as $0.17 \%$ (Table 6). While the same value was obtained in both years at $80 \mathrm{~kg} \mathrm{ha}^{-1}$ nitrogen application, relatively higher value was obtained at 40 and $60 \mathrm{~kg} \mathrm{ha}^{-1}$ nitrogen application in second year, at control group and $100 \mathrm{ha}^{-1}$ nitrogen application in first year.

Table 5. Variation of mean and standard deviation in coriander essential oil content and components cultivated in two different years

\begin{tabular}{c|c|c|c}
\hline \multirow{2}{*}{ Components (\%) } & \multirow{2}{*}{$\mathbf{R T}$} & $\mathbf{1}^{\text {st }}$ Year & $\mathbf{2}^{\text {nd }}$ Year \\
\cline { 2 - 4 } & & Mean+SD & Mean+SD \\
\hline a-pinene & 6.803 & $6.28 \pm 1.65$ & $6.58 \pm 1.78$ \\
Camphene & 8.115 & $0.73 \pm 0.18$ & $0.72 \pm 0.21$ \\
$\boldsymbol{\beta}$-pinene & 9.502 & $0.62 \pm 0.17$ & $0.61 \pm 0.16$ \\
Sabinene & 10.003 & $0.45 \pm 0.12$ & $0.44 \pm 0.12$ \\
Myrcene & 11.554 & $0.92 \pm 0.29$ & $0.92 \pm 0.24$ \\
Limonene & 12.788 & $1.9 \pm 0.60$ & $1.86 \pm 0.48$ \\
$\boldsymbol{\gamma}$-terpinene & 14.565 & $7.24 \pm 2.23$ & $7.39 \pm 1.65$ \\
p-cymene & 15.501 & $3.59 \pm 1.10$ & $3.69 \pm 0.98$ \\
Terpinolene & 15.878 & $0.34 \pm 0.19$ & $0.36 \pm 0.09$ \\
Camphor & 24.285 & $3.96 \pm 1.20$ & $3.77 \pm 0.57$ \\
Linalool & 25.254 & $57.71 \pm 6.22$ & $63.89 \pm 7.37$ \\
Terpinen-4-ol & 26.956 & $0.32 \pm 0.16$ & $0.26 \pm 0.08$ \\
a-Terpineol & 29.850 & $0.34 \pm 0.14$ & $0.31 \pm 0.06$ \\
Isoborneol & 30.027 & $0.15 \pm 0.09$ & $0.33 \pm 0.40$ \\
Geranylacetate & 31.601 & $5.56 \pm 1.94$ & $4.8 \pm 0.680$ \\
L-Citronellol & 31.753 & $0.13 \pm 0.12$ & $0.15 \pm 0.03$ \\
Geraniol & 34.147 & $2.74 \pm 1.02$ & $2.44 \pm 0.36$ \\
Dodec-2(E)-enal & 34.701 & $0.4 \pm 0.31 \mathrm{a}$ & $0.16 \pm 0.05 \mathrm{~b}$ \\
Essential Oil & & $0.18 \pm 0.02$ & $0.18 \pm 0.02$ \\
\hline
\end{tabular}

In the study about coriander, İzgi et al. (2017) stated that essential oil content of coriander varied from $0.2 \%$ to $0.6 \%$. Erdoğdu (2012), Kan (2007), Khalid, (2013) and Kirici et al. (1997) reported that the effect of nitrogen dose on the proportion of essential 
oil is statistically insignificant. However, in another study, Khalid (2015) found effect of fertilizer (nitrogen and phosphorus) on essential oil rate as positively significant $(\mathrm{p}<0.05)$ and values between $0.2 \%-0.3 \%$. Patel et al. (2013) found significant positive relation and values between $0.41-0.51 \%$. In study about response of coriander to nitrogen treatment, Lenardis et al. (2000) found that essential oil rate was increasing statistically with increasing nitrogen doses in coriander. Gil et al. (2002) stated that fertilizer (nitrogen) factor was not significant for essential oil, but year factor is significant for European coriander and interaction (year x fertilizer) factor is significant for Argentinean coriander $(\mathrm{p}<0.05)$. In their study about nitrogen doses and density effect on coriander quality, Moosavi et al. (2013) found that nitrogen doses have positive significant effect on essential oil rate of coriander and obtained values between $0.15-0.33 \%$ and tested highest value from $120 \mathrm{~kg} \mathrm{ha}^{-1}$ nitrogen application. Akbarinia et al. (2007) found that the highest essential oil rate was obtained with $90 \mathrm{~kg} \mathrm{~N}$ per hectare application.

Table 6. Variation in essential oil content and major components of essential oil of coriander (Coriandrum sativum L.) according to Year $(Y)$ and Nitrogen doses $(N)^{l}$

\begin{tabular}{|c|c|c|c|c|c|c|c|}
\hline & \multirow{2}{*}{ Years } & \multicolumn{5}{|c|}{ Nitrogen Doses $\left(\mathrm{kg} \mathrm{ha}^{-1}\right)$} & \multirow[b]{2}{*}{$\operatorname{Mean}^{Y}$} \\
\hline & & $\mathbf{0}$ & 40 & 60 & 80 & 100 & \\
\hline & $1^{\text {st }}$ & 0.17 & 0.16 & 0.16 & 0.20 & 0.19 & 0.18a \\
\hline Essential Oil (\%) & $2^{\text {nd }}$ & 0.16 & 0.21 & 0.20 & 0.20 & 0.15 & 0.18a \\
\hline \multirow[t]{2}{*}{ Factors } & $\operatorname{Mean}^{N}$ & $\begin{array}{c}0.17 d \\
Y^{N S}\end{array}$ & $0.19 b$ & $\begin{array}{c}\text { 0.18bc } \\
\mathbf{N}^{* *}\end{array}$ & $0.20 \mathrm{a}$ & $\begin{array}{l}\text { 0.18cd } \\
Y \times N^{* * *}\end{array}$ & \\
\hline & $1^{\text {st }}$ & 53.44 & 59.37 & 57.42 & 59.2 & 59.13 & 57.71b \\
\hline \multirow[t]{2}{*}{ Linalool (\%) } & $2^{\text {nd }}$ & 61.25 & 57.26 & 63.51 & 63.12 & 74.29 & 63.89a \\
\hline & $\operatorname{Mean}^{N}$ & $\begin{array}{c}\mathbf{5 7 . 3 5 b} \\
\mathbf{Y * *}\end{array}$ & $58.32 b$ & $\begin{array}{c}60.47 \mathbf{b} \\
\mathrm{N}^{*}\end{array}$ & 61.16b & $\begin{array}{l}66.71 \mathrm{a} \\
\mathrm{YxN} *\end{array}$ & \\
\hline Factors & $1^{\text {st }}$ & 3.65 & 6.77 & 8.33 & 7.77 & 9.68 & $7.24 a$ \\
\hline$\gamma$-terpinene $(\%)$ & $2^{\text {nd }}$ & 8.04 & 8.33 & 9.01 & 7.04 & 4.55 & 7.39a \\
\hline \multirow[t]{2}{*}{ Factors } & $\operatorname{Mean}^{N}$ & $\begin{array}{c}5.84 \mathrm{c} \\
\mathrm{Y}^{\mathrm{NS}}\end{array}$ & $7.55 b$ & $\begin{array}{c}8.67 \mathbf{a} \\
\mathbf{N} * *\end{array}$ & 7.4b & $\begin{array}{c}7.12 b \\
Y x N * *\end{array}$ & \\
\hline & $\mathbf{1}^{\text {st }}$ & 3.84 & 6.5 & 6.21 & 6.36 & 8.49 & $6.28 \mathrm{a}$ \\
\hline$\alpha$-pinene (\%) & $2^{\text {nd }}$ & 7.75 & 7.53 & 7.84 & 6.46 & 3.34 & $6.58 \mathrm{a}$ \\
\hline \multirow[t]{2}{*}{ Factors } & $\operatorname{Mean}^{N}$ & $\begin{array}{l}5.8 \mathrm{c} \\
\mathrm{Y}^{\mathrm{NS}}\end{array}$ & $7.02 a$ & $\begin{array}{c}7.03 a \\
\mathbf{N} * *\end{array}$ & $6.41 b$ & $\begin{array}{l}5.92 b c \\
Y \times N * *\end{array}$ & \\
\hline & $\mathbf{1}^{\text {st }}$ & 2.3 & 6.53 & 7.12 & 6.83 & 5.03 & $5.56 \mathrm{a}$ \\
\hline Geranyl acetate $(\%)$ & $2^{\text {nd }}$ & 5.06 & 5.77 & 4.38 & 4.75 & 4.02 & $4.80 \mathrm{~b}$ \\
\hline \multirow[t]{2}{*}{ Factors } & $\operatorname{Mean}^{N}$ & $\begin{array}{c}3.68 c \\
Y * *\end{array}$ & $6.15 a$ & $\begin{array}{c}\mathbf{5 . 7 5 a} \\
\mathbf{N} * *\end{array}$ & $5.79 \mathrm{a}$ & $\begin{array}{c}4.53 b \\
Y x N * *\end{array}$ & \\
\hline & $\mathbf{1}^{\text {st }}$ & 2.38 & 5.07 & 4.87 & 4.52 & 2.95 & $3.96 a$ \\
\hline Camphor (\%) & $2^{\text {nd }}$ & 3.86 & 4.49 & 3.19 & 4.12 & 3.21 & $3.77 \mathbf{a}$ \\
\hline Factors & $\operatorname{Mean}^{N}$ & $\begin{array}{c}3.12 \mathrm{c} \\
\mathrm{Y}^{\mathrm{NS}}\end{array}$ & 4.78a & $\begin{array}{c}4.03 b \\
N^{* *}\end{array}$ & $4.32 \mathrm{~b}$ & $\begin{array}{c}3.08 c \\
Y \times N^{* *} * \\
\end{array}$ & \\
\hline
\end{tabular}

${ }^{*}: \mathrm{p}<0.05 ; * *: \mathrm{p}<0.01$; NS: not significant; ${ }^{1}$ : Different letters after the same column data indicate significant difference at the 0.05 level or similar

Results in the study is suitable with Gil et al. (2002), Lenardis et al. (2000), Moosavi et al. (2013) and Patel et al. (2013). However, values are lower. It can be caused from difference of essential oil between cultivars. According to these results, it can be said that, 
ecological conditions, cultural applications and cultivars can cause differences for nitrogen effect on essential oil rate.

\section{Essential oil composition}

In the study where the effect of different doses of nitrogen in the coriander on essential oil components was determined, 18 components in total were detected (Table 5). The major components of coriander were found to be linalool, $\gamma$-terpinene, $\alpha$-pinene, geranyl acetate and camphor. It was observed significant $(\mathrm{p}<0.05)$ differences between main factor years for linalool and geranyl acetate. Mean data between nitrogen doses were statistically significant for linalool $(\mathrm{p}<0.05), \gamma$-terpinene, $\alpha$-pinene, geranyl acetate and camphor $(\mathrm{p}<0.01)$. Significant interaction was tested for linalool $(\mathrm{p}<0.05), \gamma$-terpinene, $\alpha$-pinene, geranyl acetate and camphor $(\mathrm{p}<0.01)$. Highest mean value for linalool was obtained at $100 \mathrm{~kg} \mathrm{ha}^{-1}$ nitrogen application $(66.71 \%)$. Lowest value was measured at control group (57.35\%). Linalool rate was increased by increasing nitrogen doses. Highest value $(8.67 \%)$ for $\gamma$-terpinene was obtained at $60 \mathrm{~kg} \mathrm{ha}^{-1}$ nitrogen application and lowest value $(5.84 \%)$ was obtained at control group. Highest value $(7.03 \%)$ for $\alpha$-pinene was measured at $60 \mathrm{~kg} \mathrm{ha}^{-1}$ nitrogen application and lowest value $(5.80 \%)$ was obtained at control group. For geranyl acetate, highest value $(6.15 \%)$ was obtained at $40 \mathrm{~kg} \mathrm{ha}^{-1}$ nitrogen application and lowest value $(3.68 \%)$ was obtained at control group. For camphor, highest value $(4.78 \%)$ was obtained at $40 \mathrm{~kg} \mathrm{ha}^{-1}$ nitrogen application and lowest value $(3.08 \%)$ was obtained at $100 \mathrm{~kg} \mathrm{ha}^{-1}$ nitrogen application. Regarding to components of essential oil, linalool was increase with increasing nitrogen doses, $\gamma$-terpinene was increase until $60 \mathrm{~kg} \mathrm{ha}^{-1}$ nitrogen application; $\alpha$-pinene, geranyl acetate and camphor were increase until $40 \mathrm{~kg} \mathrm{ha}^{-1}$ nitrogen application.

In their study about cultivar and location, İzgi et al. (2017) found 12 total components and 4 major components in Gamze cultivar as linalool $(74.7 \%-82.2 \%), \alpha$-pinene $(0.3 \%-4.1 \%)$, neryl acetate $(3.6 \%-6.5 \%)$ and $\gamma$-terpinene $(1.9 \%-4.2 \%)$. In his study of nitrogen treatment effect on essential oil composition of coriander, Khalid (2014) obtained 15 different contents of essential oil, and found linalool (75.5\% - 76.9\%), limonene $(6.8 \%-7.4 \%)$ and camphor $(3.7 \%$ - $3.9 \%)$ as major components of coriander and stated that values of major component differ from control group significantly. In another study about effect of micro and macro nutrients on essential oil of coriander, Khalid (2015), found that major components of essential oil in coriander (linalool, limonene and camphor) increase with increasing fertilizer (NP) doses but effect is not significant statistically. However, he found that $\alpha$-pinene increase significantly $(p<0.05)$ with fertilizer application.

The results that obtained from this study was lower than literature, but effect of fertilizer factor was suitable with literature. It can be caused from different ecological conditions, cultivars and cultural applications.

\section{Fatty oil content (\%)}

Variation in fatty oil content was given in Tables 7 and 8 . While fatty oil content was higher at second year, year differences were not statistically significant. Although highest value $(23.64 \%)$ was obtained at $80 \mathrm{~kg} \mathrm{ha}^{-1}$ nitrogen application and lowest value $(23.14 \%)$ at $40 \mathrm{~kg} \mathrm{ha}^{-1}$ nitrogen application, differences between doses were not statistically significant.

In their study about cultivar effect on coriander, Gökduman and Telci (2018) reported that mean fatty oil rate is $\mathbf{1 8 . 6 4 \%}$ for Gamze cultivar. Keskin and Baydar (2016) 
determined the mean fatty oil rate of the Gamze type as $24.62 \%$ under the ecological conditions of Isparta. Khalid (2012) found significant effect of fertilizer (NP) on fatty oil rate and values between $2.5 \%-6.8 \%$. Regarding to mean data of fatty oil, Khalid (2013) found difference of nitrogen doses significant $(\mathrm{p}<0.05)$ and values between $5.5 \%-8.2 \%$ in coriander. Values found in this study is higher than Khalid $(2012,2013)$ 's findings and same with Keskin and Baydar (2016) and Gökduman and Telci (2018).

Table 7. Variation of mean and standard deviation in coriander fatty oil content and fatty acids cultivated in two different years

\begin{tabular}{c|c|c|c}
\hline \multirow{2}{*}{ Components } & \multirow{2}{*}{ RT } & $\mathbf{1}^{\text {st }}$ Year & $\mathbf{2}^{\text {nd }}$ Year \\
\cline { 3 - 4 } & & Means+SD & Means+SD \\
\hline Butyric Acid C4:0 & 5.643 & $23.78 \pm 2.77$ & $25.15 \pm 2.37$ \\
Caproic Acid C6:0 & 6.188 & $0.08 \pm 0.06$ & $0.15 \pm 0.03$ \\
Caprylic Acid C8:0 & 7.435 & $0.01 \pm 0.03$ & $0.02 \pm 0.04$ \\
Palmitic Acid C16:0 & 18.47 & $2.60 \pm 0.27$ & $2.59 \pm 0.17$ \\
Palmitoleic Acid C16:1 & 19.642 & $0.14 \pm 0.01$ & $0.14 \pm 0.01$ \\
Stearic Acid C18:0 & 22.146 & $0.66 \pm 0.07$ & $0.65 \pm 0.05$ \\
Petroselinic Acid C18:1n9c & 23.129 & $61.77 \pm 6.33$ & $60.43 \pm 4.19$ \\
Linolelaidic Acid C18:2 & 24.134 & $0.09 \pm 0.01$ & $0.08 \pm 0.01$ \\
Linolenic Acid C18:2n & 24.641 & $10.23 \pm 1.06$ & $10.1 \pm 0.72$ \\
Arachidic Acid C20:0 & 25.604 & $0.02 \pm 0.03$ & $0.02 \pm 0.03$ \\
a-Linolenic Acid C & 26.403 & $0.06 \pm 0.03$ & $0.05 \pm 0.01$ \\
Eicosadienoic Acid C20 & 28.316 & $0.07 \pm 0.11$ & $0.11 \pm 0.05$ \\
Fatty Oil & & $23.09 \pm 2.33$ & $23.43 \pm 1.52$ \\
\hline
\end{tabular}

Table 8. Variation in fatty oil content and major fatty acids of coriander (Coriandrum sativum L.) according to Year $(Y)$ and Nitrogen doses $(N)$

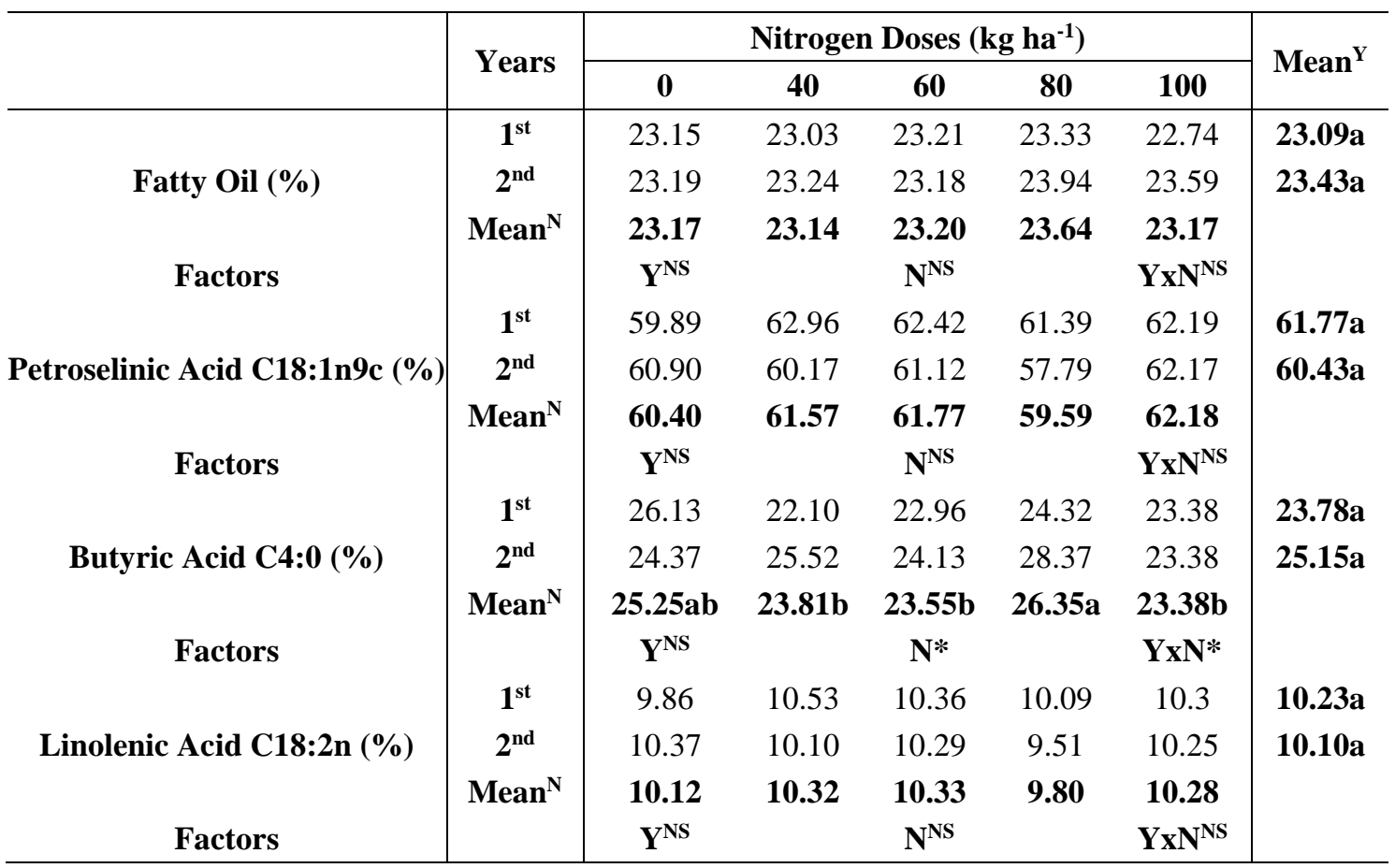

$*: \mathrm{p}<0.05 ; * *: \mathrm{p}<0.01 ; \mathrm{NS}:$ not significant 
It has been found that the effect of genetic control on the fatty oil rate in the coriander is stronger than nitrogen fertilization.

\section{Fatty acids composition (\%)}

A total of 12 fatty acids were determined in the fatty oil samples obtained from different nitrogen applications in coriander. The components of the major fatty acids were found as petroselinic acid, butyric acid and linolenic acid. Doses and interaction factor were not statistically significant for petroselinic acid and linolenic acid. Year differences were not statistically significant for major components of fatty acids. Regarding to dose differences, while highest mean value $(62.18 \%)$ for petroselinic acid was observed at $100 \mathrm{~kg} \mathrm{ha}^{-1}$ nitrogen application, mean differences between dose groups were not statistically significant. For linolenic acid, highest value (10.33) was obtained at 60 $\mathrm{kg} \mathrm{ha}^{-1}$ nitrogen application; however dose differences were not statistically significant. Doses and interaction factor were statistically significant $(\mathrm{p}<0.05)$ for butyric acid, but year factor was not significant. Statistically $(\mathrm{p}<0.05)$ highest value of butyric acid $(26.35 \%)$ was observed at $60 \mathrm{~kg} \mathrm{ha}^{-1}$ nitrogen application and lowest value was observed at $100 \mathrm{~kg} \mathrm{ha}^{-1}$ nitrogen application.

Information on the fatty acid content of coriander in order to nitrogen application in literature is very limited. Akbarinia et al. (2007) measured that highest fatty acid compositions were obtained with $90 \mathrm{~kg}$ per hectare nitrogen application. Keskin and Baydar (2016) found petroselinic acid, major component of fatty oil in coriander, at level of $79.16 \%$. Msaada et al. (2010), in their studies, where they examined the fatty oil content of coriander in different maturation periods determined 12 components, and among them, identified petroselinic $(80.36 \pm 8.45)$, linoleic $(14.12 \pm 1.35)$, palmitic $(4.09 \pm 0.42)$ and stearic $(0.66 \pm 0.05)$ acid as the major components. Ramadan and Mörsel (2002) found 12 components and reported that the main oil components and rates in coriander fruit were petroselinic acid $(65.7 \%)$ and linoleic acid (16.7\%). In the study of oil rate in different part of Tunisian coriander, Sriti et al. (2009) obtained 9 components and found petroselinic acid (74.07\%), linoleic acid (13.41\%) and oleic acid (5.91\%) as major components in fatty acids of fruit. In their study of salinity effect on coriander, Neffati and Marzouk (2008) obtained 9 different components of fatty acids and found $\alpha$-linolenic acid (24.14\%) as a major component.

According to this study, it can be concluded in literature that nitrogen fertilization has a positive effect on butyric acid in coriander fruits. The limited change in the nitrogen applications of the primary metabolite fatty acids can be explained by the fact that the control of the genetic structure in the plant is more dominant.

\section{Conclusion}

This research aims to determine the effect of nitrogen fertilization in coriander on fruit yield and quality in plain conditions of Mardin province. The results are given below as items.

1. It has been observed that nitrogen doses have an insignificant effect on fruit yield.

2. It has been tested that nitrogen doses have an insignificant effect on essential oil rate.

3. Linalool increased in parallel with increasing nitrogen doses.

4. Nitrogen fertilization did not affect fatty oil rate and other major components statistically. 
5. Year differences were not statistically significant for essential oil and fatty oil rates.

6. In coriander seeds; It has been determined that genetic control is stronger in the fruit yield, fatty oil content and fatty acids composition compared to nitrogen dose applications.

7. Since nitrogen fertilization increases the linalool ratio in the fruit and thus the essential oil quality, the use of the appropriate dose will increase the market value of the coriander product.

8. At the end of the study; In addition to the application of nitrogen dosage, additional studies on quality relationships with some other important plant nutrients, sowing time and harvest time have emerged.

\section{REFERENCES}

[1] Akbarinia, A., Daneshian, J., Mohammadbiegi, F. (2007): Effect of nitrogen fertilizer and plant density on seed yield, essential oil and oil content of Coriandrum sativum L. - Iran. J. Med. Aromat. Plants 22: 410-419.

[2] Clevenger, J. F. (1928): Apparatus for the determination of volatile oil. - J. Am. Pharm. Assoc. 17: 345-349. https://doi.org/10.1002/jps.3080170407.

[3] Duncan, D. B. (1955): Multiple range and multiple F tests. - Biometrics 11: 1-41.

[4] Erdoğdu, Y. (2012): The effect of different doses of nitrogen on yield, yield charecteristics and essential oil content of coriander (Coriandrum sativum L.). - MSc. Thesis, Namık Kemal University.

[5] Erdoğdu, Y., Esendal, E. (2018): The Effects of Nitrogen Doses on the Seed Yield and Some Agronomic Characteristics of Coriander Cultivars. - J. Tekirdag Agric. Fac. 15.

[6] Furan, M. A., Geboloğlu, M. D. (2017): Assessment of genetic variation on some cultivated Turkish coriander (Coriandrum sativum L.) varieties based on ISSR and SRAP markers. Yuz. Yil Univ. J. Agric. Sci. 27: 245-251.

[7] Gil, A., de la Fuente, E. B., Lenardis, A. E., López Pereira, M., Suárez, S. A., Bandoni, A., van Baren, C., Di Leo Lira, P., Ghersa, C. M. (2002): Coriander Essential Oil Composition from Two Genotypes Grown in Different Environmental Conditions. - J. Agric. Food Chem. 50: 2870-2877.

[8] Gökduman, G. A., Telci, İ. (2018): Determination of Yield and Quality Characteristics of Some Coriander (Coriandrum sativum L.) Genotypes in Isparta Conditions. - Süleyman Demirel Univ. J. Nat. Appl. Sci. 22(3): 1165-1168. https://doi.org/10.19113/sdufenbed.470129.

[9] Gosset, W. S. (1908): "Student". - In: The Application of the 'Law of Error' to the Work of the Brewery, pp. 3-6.

[10] IBM Corp. (2017): IBM SPSS Statistics for Windows.

[11] İzgi, M. N., Telci, İ., Elmastaş, M. (2017): Variation in essential oil composition of coriander (Coriandrum sativum L.) varieties cultivated in two different ecologies. - J. Essent. Oil Res. 29: 494-498.

[12] Jones Jr., J. B., Wolf, B., Mills, H. A. (1991): Plant analysis handbook: A practical sampling, preparation, analysis, and interpretation guide. - Micro-Macro Publishing, Inc., Athens, Georgia.

[13] Kan, Y. (2007): The effect of organic and inorganic fertilizer on yield and essential oil of coriander (Coriandrum sativum L.) growing in Konya ecological conditions. - Selcuk J. Agric. Food Sci. 21: 36-42.

[14] Kandemir, K. (2010): The effect of different nitrogen doses and row spaces on yield and yield components in coriander. - Ordu University. 
[15] Karadoğan, T., Özer, H., Arpacioğlu, K. (1997): Azot ve fosforla gübrelemenin kişniş bitkisinin (Coriandrum sativum L.) verim ve verim unsurları üzerine etkisi. - Türkiye II. Tarla Bitk. Kongresi, pp. 674-676.

[16] Keskin, S., Baydar, H. (2016): Agricultural and technological properties of some important culture species within the family Umbelliferaein Isparta ecological conditions. - Süleyman Demirel Univ. J. Nat. Appl. Sci. 20: 133-141.

[17] Khalid, K. A. (2012): Effect of phosphorous fertilization on anise, coriander and sweet fennel plants growing under arid region conditions. - Med. Aromat. Plant Sci. Biotechnol. 6: $127-131$.

[18] Khalid, K. A. (2013): Effect of nitrogen fertilization on morphological and biochemical traits of some Apiaceae crops under arid regions in Egypt. - Nusant. Biosci. 5: 15-21.

[19] Khalid, K. A. (2014): Essential oil composition of some spices treated with nitrogen in arid regions. - Int. Food Res. J. 21(6): 2305-2309.

[20] Khalid, K. A. (2015): Effect of macro and micro nutrients on essential oil of coriander fruits. - JMESCN 6(8): 2060-2065.

[21] Kirıc1, S., Mert, A., Ayanoğlu, F. (1997): The effect of nitrogen and phosphorus on essential oil content and yield values of coriander (Coriandrum sativum L.) at Hatay ecology. - In: $2^{\text {nd }}$ Field Crops Congress of Turkey, September, 22-25, 1997, Proceedings, Samsun, pp. 347-351.

[22] Lenardis, A., de la Fuente, E., Gil, A., Tubía, A. (2000): Response of coriander (Coriandrum sativum L.) to nitrogen availability. - J. Herbs. Spices Med. Plants 7: 47-58. https://doi.org/10.1300/J044v07n04_06.

[23] Marschner, H. (2011): Marschner's mineral nutrition of higher plants. $-3^{\text {rd }}$ ed. Academic Press.

[24] Moosavi, G., Seghatoleslami, M., Ebrahimi, A., Fazeli, M., Jouyban, Z. (2013): The effect of nitrogen rate and plant density on morphological traits and essential oil yield of coriander. - J. Ornam. Plants 3(2): 95-103.

[25] Msaada, K., Hosni, K., Ben Taarit, M., Hammami, M., Marzouk, B. (2010): Oil yield and fatty acid composition of coriander (Coriandrum sativum L.) fruit as influenced by different stages of maturity. - Riv. Ital. Sost. Grasse 87: 268-275.

[26] Nayak, B. R., Saini, S. S., Sahu, G. S. (2009): Effect of farm yard manure, nitrogen and plant spacings on yield and attributing character of coriander (Coriandrum sativum L.). Environ. Ecol. 27: 1374-1377.

[27] Neffati, M., Marzouk, B. (2008): Changes in essential oil and fatty acid composition in coriander (Coriandrum sativum L.) leaves under saline conditions. - Ind. Crops Prod. 28: 137-142. https://doi.org/10.1016/j.indcrop.2008.02.005.

[28] Okut, N., Y1ldırım, B. (2005): Effects of different row spacing and nitrogen doses on certain agronomic characteristics of coriander (Coriandrum sativum L.). - Pakistan J. Biol. Sci. 8: 901-904.

[29] Patel, C. B., Amin, A. U., Patel, A. L. (2013): Effect of varying levels of nitrogen and sulphur on growth and yield of coriander (Coriandrum sativum L.). - The Bioscan 8: 12851289.

[30] Pawar, P. M., Naik, D. M., Damodhar, V. P., Shinde, V. N., Bhalerao, R. V. (2007): Influence of graded levels of spacing and nitrogen on growth and yield of coriander (Coriandrum sativum L.). - Asian J. Hortic. 2: 58-60.

[31] Ramadan, M., Mörsel, J.-T. (2002): Oil composition of coriander (Coriandrum sativum L.) fruit-seeds. - Eur. Food Res. Technol. 215: 204-209. https://doi.org/10.1007/s00217-0020537-7.

[32] Reddy, K., Rolston, M. P. (1997): Achievement of maximum seed yield in coriander (Coriandrum sativum L.). - In: Proceedings Agronomy Society of NZ. p. 37.

[33] SAS Institute Inc. (2002): JMP®. 
[34] Shahwar, M. K., El-Ghorab, A. H., Anjum, F. M., Butt, M. S., Hussain, S., Nadeem, M. (2012): Characterization of coriander (Coriandrum sativum L.) seeds and leaves: Volatile and non volatile extracts. - Int. J. Food Prop. 15: 736-747.

[35] Sriti, J., Talou, T., Wannes, W. A., Cerny, M., Marzouk, B. (2009): Essential oil, fatty acid and sterol composition of Tunisian coriander fruit different parts. - J. Sci. Food Agric. 89: 1659-1664.

[36] Telci, İ., Bayram, E., Avc1, B. (2006a): Changes in yields, essential oil and linalool contents of Coriandrum sativum varieties (var. vulgare Alef. and var. microcarpum DC.) harvested at different development stages. - Eur. J. Hortic. Sci. 71: 267.

[37] Telci, İ., Tonçer, Ö. G., Şahbaz, N. (2006b): Yield, essential oil content and composition of Coriandrum sativum varieties (var. vulgare Alef and var. microcarpum DC.) grown in two different locations. - J. Essent. Oil Res. 18: 189-193

[38] Telci, İ., Demirtas, İ., Bayram, E., Arabacı, O., Kacar, O. (2010): Environmental variation on aroma components of pulegone/piperitone rich spearmint (Mentha spicata L.). - Ind. Crops Prod. 32: 588-592. 